Magdalena LORENC

Uniwersytet im. Adama Mickiewicza, Poznań

\title{
Polska opinia publiczna wobec działań PKW w Afganistanie i Iraku
}

Daździernik 2008 roku stanowi istotną cezurę w historii najnowszej Wojska Polskiego (WP). 25 października 2008 roku Irak opuściła ostatnia dziesiąta zmiana Polskiego Kontyngentu Wojskowego (PKW), uczestniczącego w tzw. misji stabilizacyjnej. 10 października 2008 roku prezydent Lech Kaczyński przedłużył obecność PKW w Afganistanie w ramach Międzynarodowych Sił Wspierania Bezpieczeństwa (ang. International Security Assistance Force, ISAF).

Udział polskich żołnierzy w akcjach zbrojnych będących reakcją na wydarzenia z 11 września 2001 roku, prowokuje pytanie o stosunek opinii publicznej do „wojny z terroryzmem” oraz decyzji władz RP o wysłaniu PKW do Afganistanu i Iraku. Podstawę niniejszego artykułu stanowią wyniki badań przeprowadzonych przez Centrum Badania Opinii Społecznej (CBOS) w latach 2001-2008 na reprezentatywnej próbie losowo-adresowej dorosłych mieszkańców Polski ${ }^{1}$.

\section{Stosunek do działań PKW w Afganistanie}

Zamachy terrorystyczne na World Trade Center (WTC) i Pentagon zdeterminowały politykę zagraniczną amerykańskiej administracji w okresie prezydentury George'a W. Busha. W oparciu o dane agencji wywiadowczych, Stany Zjednoczone odpowiedzialnością za ataki z 11 września 2001 roku obciążyły saudyjskiego szejka Osamę bin Ladena i kierowaną przez niego al-Kaidę. Przejawem solidarności z USA i efektem zabiegów amerykańskiej dyplomacji był powszechny udział państw w ogłoszonej przez prezydenta Busha „wojnie z terroryzmem”. Przebywający na terenie rządzonego przez Talibów Afganistanu przywódcy al-Kaidy stali się celem, rozpoczętej 7 października 2001 roku, akcji zbrojnej sił koalicji międzynarodowej.

1 Badania prowadzano każdorazowo na grupie około 1 tys. osób. 
Postanowieniem prezydenta Aleksandra Kwaśniewskiego z 20 listopada 2001 roku PKW wszedł w skład Sił Sojuszniczych w Afganistanie, Tadżykistanie i Uzbekistanie oraz na Morzu Arabskim i Oceanie Indyjskim $^{2}$. Skierowana 16 marca 2002 roku pierwsza grupa polskich żołnierzy zajmowała się głównie organizacją zaplecza logistycznego dla sił koalicji i rozminowaniem terenu. W pierwszym roku trwania operacji skład PKW zmniejszono o przeszło połowę z 300 do około 120 żołnierzy ${ }^{3}$. Mimo nieangażowania się kontyngentu $\mathrm{w}$ działania ofensywne, nie zdołano uniknąć ofiar. W ciągu pierwszych trzech zmian PKW w Afganistanie zginęło ośmiu polskich żołnierzy.

Wraz z czwartą zmianą i postanowieniem Prezydenta RP z 22 listopada 2008 roku wielkość kontyngentu została określona na maksymalnym poziomie 1,6 tys. osób. Przedefiniowaniu uległ także cel obecności PKW. Kluczowe od przeszło sześciu lat zadania inżynieryjne, zastąpiono zwalczaniem ugrupowań zbrojnych, szkoleniem afgańskiej policji oraz organizacją posterunków kontrolnych.

Działania ISAF w których uczestniczyły siły Paktu Północnoatlantyckiego wraz z PKW, prowadzone były na podstawie rezolucji Rady Bezpieczeństwa $\mathrm{ONZ}^{4}$ oraz porozumienia z Bonn z 5 grudnia 2001 roku, dotyczącego tymczasowych ustaleń w sprawie odbudowy stałych instytucji rządowych w Afganistanie 5 .

„Polska przyłączyła się do walki z terroryzmem z wielkim przekonaniem" - stwierdził polski minister spraw zagranicznych Włodzimierz Cimoszewicz ${ }^{6}$. Wypowiedź ministra oddawała nastroje panujące w polskim społeczeństwie. W przeprowadzonym kilka dni po zamachach na WTC i Pentagon (13-16 września 2001 roku) badaniu opinii publicznej, zdecy-

2 Monitor Polski, Nr 42, poz. 674, z późn. zm.

3 Dane za oficjalną stroną PKW w Afganistanie: http://www.isaf.wp.mil.pl/kontyngent.html [13.05.2008].

4 Rezolucje Rady Bezpieczeństwa ONZ nr 1386 (20 grudnia 2001 roku), nr 1510 (13 października 2003 roku), nr 1563 (17 września 2004 roku), nr 1623 (13 września 2005 roku) i nr 1707 (13 września 2006 roku).

5 Oficjalna strona PKW w Afganistanie: http://www.isaf.wp.mil.pl/kontyngent.html [13.05.2008].

6 Cyt. za: Wystapienie ministra spraw zagranicznych W. Cimoszewicza na konferencji Wzmacnianie stabilności w Europie Środkowej. Praktyczne podejście do regionalnego i subregionalnego wspólnego bezpieczeństwa (Warszawa, 11 marca 2002 r.) [wersja elektroniczna], http://www.zbiordokumentow.pl/2002/1/ZD1-02\%2005.pdf, s. $44[12.05 .2008]$. 
dowana większość (89\% przy zaledwie 5\% sprzeciwie) respondentów była przekonana, że zamachy terrorystyczne w Stanach Zjednoczonych spowodują ,zjednoczenie się całego cywilizowanego świata w walce z terroryzmem" "7 . Równocześnie 77\% (12\% było przeciwnego zdania) ankietowanych, gotowych było poprzeć zaangażowanie Polski w ewentualną akcję zbrojną NATO, skierowaną przeciwko organizatorom ataków terrorystycznych w USA ${ }^{8}$. Udział Polski w operacji NATO stanowić miał dowód na wypełnianie zobowiązań sojuszniczych. Jednak już w ciagu miesiąca od dnia zamachów, znacząco zmalało poparcie polskiej opinii społecznej wobec koncepcji włączenia PKW w operację antyterrorystyczną NATO. Rozpoczęcie 7 października 2001 roku akcji zbrojnej przeciwko Talibom, wpłynęło na spadek aprobaty dla możliwości militarnego zaangażowania Polski w ,wojnę z terroryzmem”, aż o 17 punktów procentowych względem stanu z połowy września 2001 roku'. Równocześnie odnotowano ponad dwukrotny wzrost przeciwników wysłania PKW na misję w ramach NATO, z 12\% we wrześniu do $29 \%$ w październiku. W listopadzie 2001 roku, nadal większość (54\% przy 33\% sprzeciwie) respondentów uważała, że Polska powinna uczestniczyć w operacji NATO w Afganistanie. Dopiero w grudniu 2001 roku liczba zwolenników (48\%) udziału PKW w misji zbliżyła się do liczby przeciwników zaangażowania, szacowanej na $43 \%$. Podobnie respondenci zareagowali na postawione po raz pierwszy pod koniec 2001 roku pytanie, dotyczące podjętej przez rząd RP w listopadzie decyzji o wysłaniu 300-osobowego polskiego kontyngentu do Afganistanu. Ankietowani podzielili się wówczas niemal po połowie, dając wynik: $45 \%$ zwolenników i $44 \%$ przeciwników. Spadek poparcia utrzymał się do stycznia 2002 roku, osiagając identyczny wynik 43\% w odniesieniu do zwolenników oraz przeciwników decyzji władz RP o wysłaniu polskich żołnierzy do Afganistanu ${ }^{10}$.

7 Przewidywane konsekwencje ataku terrorystycznego na USA, CBOS, komunikat $\mathrm{z}$ badań BS/126/2001 [wersja elektroniczna], http://www.cbos.pl/SPISKOM.POL/2001/K_126_01.PDF [12.05.2008].

${ }^{8}$ Czy Polsce zagraża terroryzm?, CBOS, komunikat z badań BS/123/2001 [wersja elektroniczna], http://www.cbos.pl/SPISKOM.POL/2001/K_123_01.PDF [14.05.2008].

9 Opinie o wyjeździe polskich żotnierzy do Afganistañu i działaniach antyterrorystycznych NATO, CBOS, komunikat z badań BS/4/2002 [wersja elektroniczna], http://www.cbos.pl/SPISKOM.POL/2002/K_004_02.PDF [15.10.2008].

10 O przynależności Polski do NATO i obecności polskich żolnierzy w Afganistanie, CBOS, komunikat z badań BS/73/2002 [wersja elektroniczna], http://www.cbos.pl/SPISKOM.POL/2002/K_073_02.PDF [16.10.2008]. 
Kolejne badanie przeprowadzone w kwietniu 2002 roku, miesiąc po wyjeździe z kraju pierwszej grupy żołnierzy, wykazało zmianę nastawienia i zdecydowany wzrost liczby osób popierających udział PKW w misji afgańskiej (57\% za, 32\% przeciw).

Widocznemu w ostatnich miesiącach 2001 roku sceptycyzmowi dla koncepcji obecności polskich żołnierzy w Afganistanie, towarzyszył wzrost akceptacji dla działań koalicji antyterrorystycznej, która w grudniu 2001 roku osiągnęła $69 \%$ przy $24 \%$ głosów sprzeciwu ${ }^{11}$. Apogeum przychylnego nastawienia przypadło na kwiecień 2002 roku, kiedy to trzy czwarte ankietowanych (75\%) deklarowało poparcie dla działań koalicji antyterrorystycznej w Afganistanie, przy zaledwie 18\% głosów sprzeciwu ${ }^{12}$.

Aprobacie Polaków dla misji afgańskiej ujawnionej w badaniach prowadzonych od października 2001 roku do kwietnia 2002 roku, towarzyszyła niewiara w możliwość likwidacji terroryzmu międzynarodowego. Mimo wysiłków wojsk koalicji w październiku i grudniu 2001 roku prawie połowa (49\%) respondentów stwierdzała, niemożność wyeliminowania terroryzmu przy odpowiednio: $35 \%$ i 37\% głosów przeciwnych $^{13}$.

Stopniowe ograniczanie w 2002 roku doniesień medialnych dotyczących przebiegu kampanii afgańskiej i rozpoczęcie 20 marca 2003 roku operacji Iracka Wolność, spowodowało spadek zapotrzebowania na sondaże poświęcone działaniom PKW $\mathrm{w}$ ramach misji ISAF.

W przeprowadzonych 6-9 października 2006 roku badaniach pytano o stosunek do udziału polskich żołnierzy w misjach poza granicami kraju. Ankietowani odnieśli się także do decyzji władz RP o zwiększeniu polskiego kontyngentu w Afganistanie. Zgodnie z komunikatem CBOS, aż $76 \%$ respondentów sprzeciwiało się planom wysłania kolejnego 1 tys. żołnierzy, natomiast tylko $16 \%$ wyraziło aprobatę ${ }^{14}$. Na wyeksponowanie zasługuje kategoryczny sprzeciw aż $47 \%$ badanych wobec planów rządu.

11 Afganistan: Wyjazd polskich żotnierzy i opinie o działaniach NATO, CBOS, komunikat z badań BS/19/2002 [wersja elektroniczna], http:/www.cbos.pl/SPISKOM.POL/2002/K_019_02.PDF [16.10.2008].

12 O przynależności Polski do NATO..., op. cit.

13 Afganistan: Wyjazd..., op. cit.

14 Opinia publiczna o udziale polskich żolnierzy $w$ misjach poza granicami kraju, CBOS, komunikat z badań BS/161/2006 [wersja elektroniczna], http://www.cbos.pl/SPISKOM.POL/2006/K_161_06.PDF [20.10.2008]. 
Negatywny stosunek większości ankietowanych do zwiększenia zaangażowania kadrowego PKW w Afganistanie, znalazł odzwierciedlenie w dominującej w latach 2007-2008 dezaprobacie dla udziału Polaków w misji ISAF. W badaniach prowadzonych od stycznia 2007 roku do września 2008 roku około trzy czwarte polskiego społeczeństwa było przeciwnych obecności PKW w Afganistanie. Apogeum dezaprobaty odnotowano w grudniu 2007 roku, w którym aż 83\% respondentów było przeciwnych udziałowi Polaków w misji afgańskiej przy zaledwie 14\% zwolenników ${ }^{15}$.

Tabela 1

Poparcie dla udziału polskich żołnierzy w operacji NATO w Afganistanie w latach 2007-2008

\begin{tabular}{|c|c|c|c|c|c|c|c|c|c|c|c|c|c|c|c|c|c|c|c|}
\hline \multirow{3}{*}{\begin{tabular}{|l} 
Czy popiera Pan(i) \\
udział żołnierzy pol- \\
skich w operacji \\
NATO w Afganista- \\
nie czy też nie?
\end{tabular}} & \multicolumn{19}{|c|}{ Wskazania respondentów według terminów badań } \\
\hline & \multicolumn{2}{|c|}{$\begin{array}{c}\text { I } \\
2007\end{array}$} & \multicolumn{2}{|c|}{$\begin{array}{c}\text { VI } \\
2007\end{array}$} & \multicolumn{2}{|c|}{$\begin{array}{c}\text { VII } \\
2007\end{array}$} & \multicolumn{2}{|c|}{$\begin{array}{c}\text { IX } \\
2007\end{array}$} & \multicolumn{2}{|c|}{$\begin{array}{c}X \\
2007\end{array}$} & \multicolumn{2}{|c|}{$\begin{array}{c}\text { XII } \\
2007\end{array}$} & \multicolumn{2}{|c|}{$\begin{array}{c}\text { II } \\
2008\end{array}$} & \multicolumn{2}{|c|}{$\begin{array}{c}\text { IV } \\
2008\end{array}$} & \multicolumn{3}{|c|}{$\begin{array}{c}\text { IX } \\
2008\end{array}$} \\
\hline & \multicolumn{19}{|c|}{ w procentach } \\
\hline \begin{tabular}{|l|}
$\begin{array}{l}\text { Zdecydowanie po- } \\
\text { pieram }\end{array}$ \\
\end{tabular} & 5 & \multirow[t]{2}{*}{20} & 3 & \multirow[t]{2}{*}{317} & 4 & \multirow[t]{2}{*}{18} & 5 & \multirow[t]{2}{*}{22} & 4 & \multirow[t]{2}{*}{19} & 3 & \multirow[t]{2}{*}{14} & 6 & \multirow[t]{2}{*}{22} & 4 & \multirow[t]{2}{*}{18} & & \multirow{2}{*}{\multicolumn{2}{|c|}{21}} \\
\hline Raczej popieram & 15 & & 14 & & 14 & & 17 & & 15 & & 11 & & 16 & & 17 & & & & \\
\hline Raczej nie popieram & 30 & \multirow[b]{2}{*}{75} & 30 & \multirow[b]{2}{*}{78} & 27 & \multirow[b]{2}{*}{77} & 32 & \multirow[b]{2}{*}{72} & 26 & \multirow[b]{2}{*}{77} & 22 & \multirow[b]{2}{*}{83} & 30 & \multirow[b]{2}{*}{73} & 1 & \multirow[b]{2}{*}{77} & & 7 & \\
\hline $\begin{array}{l}\text { Zdecydowanie nie } \\
\text { popieram }\end{array}$ & 45 & & 48 & & 50 & & 40 & & 51 & & 61 & & 43 & & 46 & & 4 & 77 & \\
\hline Trudno powiedzieć & 5 & & & & 5 & 5 & 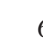 & 6 & & 4 & 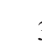 & 5 & & 5 & & 5 & & 5 & \\
\hline
\end{tabular}

Źródło: Stosunek do operacji militarnej w Afganistanie, CBOS, komunikat z badań BS/142/2008 [wersja elektroniczna], http://www.cbos.pl/SPISKOM.POL/2008/K_142_08.PDF [22.10.2008].

Sceptycznie postrzegano także możliwość zrealizowania celu misji, którym, po odsunięciu od władzy wspierających działalność terrorystyczną Talibów, stało się przywrócenie pokoju i stabilizacja sytuacji wewnętrznej w Afganistanie. W badaniach prowadzonych od czerwca 2007 roku do kwietnia 2008 roku dominowała niewiara w możliwość zaprowadzenia pokoju w konsekwencji działań sił NATO.

15 Stosunek do operacji militarnej $w$ Afganistanie, CBOS, komunikat z badań BS/142/2008 [wersja elektroniczna], http://www.cbos.pl/SPISKOM.POL/2008/K 142 08.PDF [22.10.2008]. 
Opinie na temat możliwości zaprowadzenia pokoju w Afganistanie w konsekwencji działań NATO w latach 2007-2008

\begin{tabular}{|c|c|c|c|c|c|c|c|c|c|c|c|c|}
\hline \multirow{3}{*}{\begin{tabular}{||l|} 
Czy uważa Pan(i), że \\
operacja NATO w Af- \\
ganistanie przyczyni się \\
do zapanowania pokoju \\
w tym kraju czy też nie?*
\end{tabular}} & \multicolumn{12}{|c|}{ Wskazania respondentów według terminów badań } \\
\hline & \multicolumn{2}{|c|}{$\begin{array}{c}\text { VI } \\
2007\end{array}$} & \multicolumn{2}{|c|}{$\begin{array}{c}\text { VII } \\
2007\end{array}$} & \multicolumn{2}{|c|}{$\begin{array}{c}\text { IX } \\
2007\end{array}$} & \multicolumn{2}{|c|}{$\begin{array}{c}\mathbf{X} \\
\mathbf{2 0 0 7}\end{array}$} & \multicolumn{2}{|c|}{$\begin{array}{c}\text { II } \\
2008 \\
\end{array}$} & \multicolumn{2}{|c|}{$\begin{array}{c}\text { IV } \\
2008\end{array}$} \\
\hline & \multicolumn{12}{|c|}{ w procentach } \\
\hline Zdecydowanie tak & 2 & \multirow{2}{*}{16} & 2 & \multirow{2}{*}{16} & 3 & \multirow{2}{*}{21} & 2 & \multirow{2}{*}{17} & 3 & \multirow{2}{*}{20} & 3 & \multirow{2}{*}{18} \\
\hline Raczej tak & 14 & & 14 & & 18 & & 15 & & 17 & & 15 & \\
\hline Raczej nie & 44 & \multirow{2}{*}{71} & 38 & \multirow{2}{*}{69} & 38 & \multirow{2}{*}{61} & 39 & \multirow{2}{*}{73} & 41 & \multirow{2}{*}{65} & 42 & \multirow{2}{*}{67} \\
\hline Zdecydowanie nie & 27 & & 31 & & 23 & & 34 & & 24 & & 25 & \\
\hline Trudno powiedzieć & \multicolumn{2}{|c|}{13} & \multicolumn{2}{|c|}{15} & \multicolumn{2}{|c|}{18} & \multicolumn{2}{|c|}{10} & \multicolumn{2}{|c|}{15} & \multicolumn{2}{|c|}{15} \\
\hline
\end{tabular}

* Od czerwca do września 2007 roku pytanie zadawano w następującym brzmieniu: Czy uważa Pan(i), że operacja militarna NATO w Afganistanie przyczyni się do zapanowania pokoju w tym kraju?

Źródło: Zagraniczne misje zbrojne w opinii Polaków, CBOS, komunikat z badań BS/76/2008 [wersja elektroniczna], http://www.cbos.pl/SPISKOM.POL/2008/K_076_08.PDF [12.12.2008].

\section{Stosunek do działań PKW w Iraku}

Osiagniętej dzięki zabiegom dyplomatycznym szerokiej koalicji w konfrontacji z Talibami, nie zdołano powtórzyć w Iraku. Brak mandatu ONZ i niepotwierdzone zarzuty, dotyczące posiadania przez Irak broni masowego rażenia oraz wspierania terroryzmu, wzbudziły kontrowersje wśród części sojuszników z misji afgańskiej.

Przystąpienie Polski do koalicji mającej na celu rozbrojenie Iraku było efektem konsensusu elit politycznych w Warszawie. W przedstawionym na początku 2003 roku exposé ministra Cimoszewicza, akcja zbrojna przeciwko Irakowi była ostatecznością, którą „Polska gotowa była poprzeć" ${ }^{\prime 16}$. Postanowieniem prezydenta Aleksandra Kwaśniewskiego z 17 marca 2003 roku, PKW miał zostać użyty w składzie Wielonarodowych Połączonych Sił Operacyjnych. Poparcie dla akcji zbrojnej „było wyra-

16 Cyt. za: Informacja rzqdu na temat polskiej polityki zagranicznej w 2003 roku (przedstawiona przez ministra spraw zagranicznych Włodzimierza Cimoszewicza), „Rocznik Polskiej Polityki Zagranicznej” 2004, s. 20. 
zem sojuszniczej wiarygodności i elementem budowy strategicznego partnerstwa" ${ }^{\prime 7}$ Polski ze Stanami Zjednoczonymi.

Strona polska podjęła się dowodzenia Wielonarodową Dywizją Centralno-Południową (ang. Multinational Division Central-South, MNDCS) i wystawiła dziesięć zmian kontyngentu narodowego. Na przestrzeni lat zmieniał się skład i charakter zadań wykonywanych w ramach operacji Iracka Wolność. Pierwsza zmiana PKW liczyła około 2,5 tys. osób, natomiast ostatnia, dziesiąta - około 900 żołnierzy i pracowników wojska ${ }^{18}$. Fakt kierowania dywizją wielonarodową był w opinii polskiej generalicji doświadczeniem bez precedensu, podobnie jak dowodzenie najliczniejszym kontyngentem wystawionym przez Siły Zbrojne RP od czasów drugiej wojny światowej (wyłączając inwazję na Czechosłowację w 1968 roku). Organizacja zmian polskiego kontyngentu była znaczącym przedsięwzięciem logistycznym i sprawdzianem bojowym WP, a także obciążeniem dla budżetu państwa szacowanym na ponad miliard złotych.

Postanowienie prezydenta Kwaśniewskiego o wysłaniu żołnierzy WP do Iraku było sprzeczne z oczekiwaniami większości społeczeństwa. Badania opinii publicznej przeprowadzone przez CBOS pod koniec 2002 roku wykazały, że jedna trzecia (34\%) respondentów negatywnie oceniała możliwość zbrojnej interwencji w Iraku ${ }^{19}$. Kolejne $20 \%$ uważało, że jeżeli Komisja Narodów Zjednoczonych do spraw Monitorowania, Weryfikacji i Inspekcji (ang. United Nations Monitoring, Verification and Inspection Commission, UNMOVIC) nie ujawni posiadania przez Irak broni masowego rażenia, nie powinno dojść do ataku. Jedynie $6 \%$ badanych poparło interwencję bezwarunkowo, natomiast $25 \%$ gotowe było zaaprobować operację po udowodnieniu przez inspektorów ONZ, że Irak jest w posiadaniu broni masowego rażenia. Ponieważ nie zdołano dowieść łamania przez Saddama Husajna zakazu, wprowadzonego przez ONZ po pierwszej wojnie w Zatoce Perskiej, można stwierdzić, że zdecydowana większość ankietowanych była przeciwna akcji zbrojnej i okupacji Iraku.

Jak zauważył wiceminister spraw zagranicznych Adam D. Rotfeld, intencją polskich władz „nie była jednak okupacja Iraku, lecz udział w misji

17 Ibidem.

18 Dane za oficjalną stroną internetową PKW w Iraku: http://www.pkwirak.wp.mil.pl/pl/index.html [22.06.2008].

19 Czy powinno dojść do wojny z Irakiem?, CBOS, komunikat z badań BS/2/2003 [wersja elektroniczna], http://www.cbos.pl/SPISKOM.POL/2003/K_002_03.PDF [15.05.2008]. 
stabilizacyjnej"20 . Zapewnienia ministra nie uwzględniały faktu, że podstawę prawną obecności PKW w Iraku stanowiły uzgodnienia zawarte z okupacyjnymi Tymczasowymi Władzami Koalicyjnymi. Dopiero rezolucje Rady Bezpieczeństwa ONZ oraz porozumienia z pochodzącymi z wyborów irackimi władzami, spowodowały legitymizację działań sił koalicji.

Badania CBOS z lipca 2003 roku, poprzedzające przejęcie kontroli nad strefą stabilizacyjną ujawniły, że ankietowani nie aprobowali decyzji rządzących, związanej z wysłaniem PKW do Iraku ${ }^{21}$. Dezaprobata 55\% respondentów, przy zaledwie 36\% akceptacji udziału Polaków w misji, dowodziła krytycznego stosunku do działań w Iraku. Reprezentatywnej grupie osób zadano także pytanie o związek między obecnością polskich żołnierzy w Iraku, a ryzykiem ataków terrorystycznych ze strony fundamentalistów islamskich. Wówczas $68 \%$ badanych wyraziło obawę, że w konsekwencji misji PKW w Iraku, Polska może stać się celem zamachów. Poczucie zagrożenia utrzymywało się przez niemal cały okres obecności żołnierzy polskich w Iraku, osiągając apogeum (tj. 87\%) po zamachach w Madrycie z 11 marca 2004 roku $^{22}$.

Władze RP nie podzielały obaw związanych z ryzykiem ataków terrorystycznych na terytorium Polski i deklarowały, że „będą z przekonaniem kontynuować zaangażowanie w koalicji antyterrorystycznej"23.

Kolejne badanie opinii publicznej przeprowadzone na początku września 2003 roku, w kilka dni po przejęciu kontroli nad strefą centralno-południową w Iraku, ujawniło wzrost społecznego poparcia dla udziału polskich żołnierzy w misji do poziomu 40\% (przy sprzeciwie 53\%) i przeświadczenie połowy ankietowanych ( $30 \%$ było przeciwnego zdania), że

20 Cyt. za: A. D. Rotfeld, Nie będziemy okupantami, „Gazeta Wyborcza” nr 118, 2003, s. 13.

${ }^{21}$ Opinie o obecności polskich żolnierzy w Iraku, CBOS, komunikat z badań BS/123/2003 [wersja elektroniczna], http://www.cbos.pl/SPISKOM.POL/2003/K 123 03.PDF [17.05.2008].

${ }^{2 \overline{2}}$ Wrost poczucia zagrożenia terroryzmem, CBOS, komunikat z badań BS/59/2004 [wersja elektroniczna], http://www.cbos.pl/SPISKOM.POL/2004/K_059_04.PDF [17.05.2008]. Zmianę opinii wykazał dopiero sondaż przeprowadzony w lutym 2008 roku, w którym przekonani o zagrożeniu terytorium Polski atakami terrorystycznymi stanowili 40\% mniejszość, w stosunku do 49\% niedostrzegających takiego niebezpieczeństwa.

${ }^{23}$ Cyt. za: Informacja rzqdu na temat polskiej polityki zagranicznej w 2004 roku..., op. cit., s. 20 . 
$\frac{1}{0}$
$\frac{\pi}{0}$
$\frac{\pi}{0}$



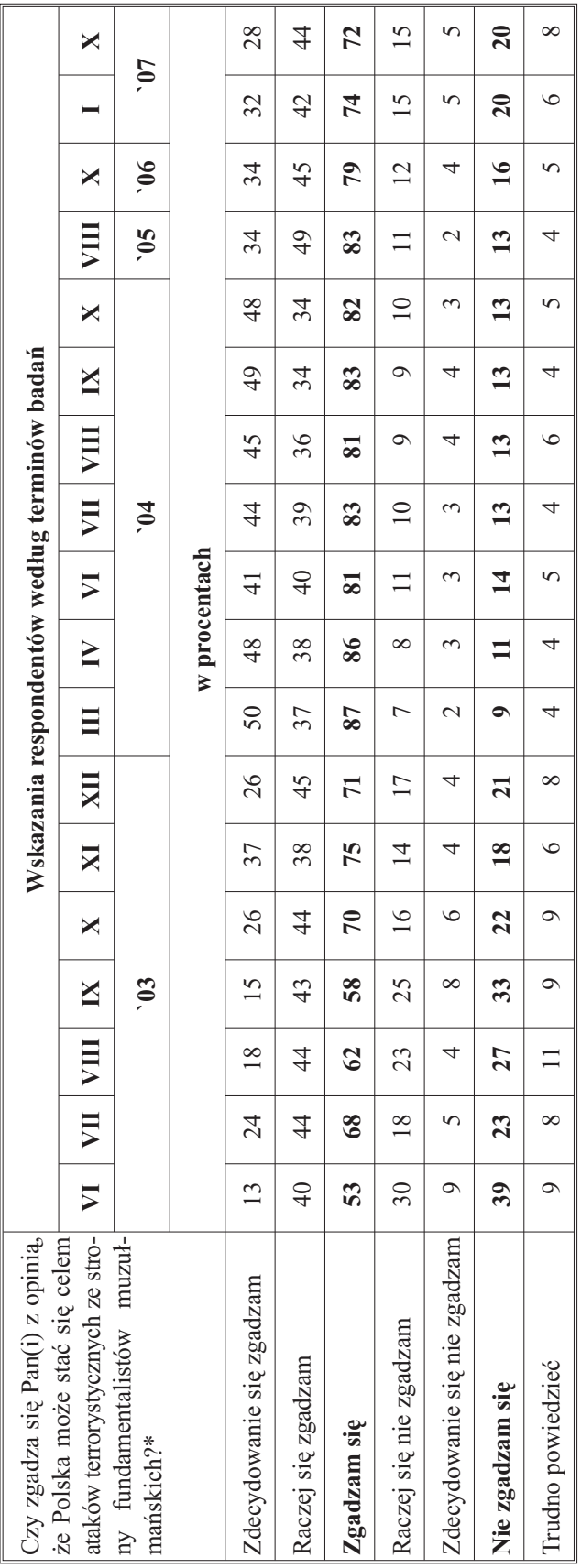

กี้

$\frac{\pi}{5}$

อ

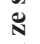

$\because \hat{\circ}$

ไิ่

造

한

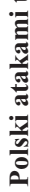

.ํㅗㄹ

ำ

ง

葛

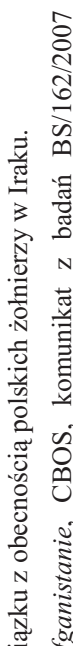

.

is

는

$\stackrel{2}{2}$

원

每

है

을

+ 8

(1)

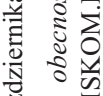

诺 8

ठ ㅎำ

仓ิ

ते

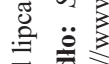


PKW zdoła pomyślnie wywiązać się z powierzonych zadań ${ }^{24}$. Podstawowym atutem Polaków - zdaniem badanych - był stan i przygotowanie kadry wojskowej. Największą słabość naszego kontyngentu, stanowiły natomiast ograniczone możliwości finansowe krajowego budżetu.

Pojawienie się pierwszej ofiary śmiertelnej w polskich szeregach, doprowadziło do znacznego wzrostu przeciwników obecności PKW w Iraku do poziomu $67 \%$ (przy $28 \%$ zwolenników) ${ }^{25}$. Zmianie uległo także zdanie badanych w kwestii korzyści finansowych, jakie przyniesie Polsce pomoc Amerykanom w obaleniu dyktatury Saddama Husajna. Zwraca uwagę odwrócenie proporcji, między przeświadczeniem $41 \%$ badanych z maja 2003 roku o dominacji profitów nad stratami (21\% było przeciwnego zdania), a listopadowym wzrostem do poziomu $53 \%$ przekonanych o braku wymiernych efektów finansowych militarnego zaangażowania (przy zaledwie 14\% wskazaniu przez respondentów korzyści). Znacząca zmiana dotyczyła także korzyści politycznych, których w maju 2003 roku spodziewało się 37\% ankietowanych (przy 16\% pewnych strat), natomiast w listopadzie zaledwie 20\% (przy 40\% przekonanych o stratach). Najmniejsze różnice dotyczyły wizerunku Polski w świecie, który pozytywnie oceniła większość ankietowanych (ponad 30\% w obu badaniach). Po raz pierwszy CBOS, zapytało o zdanie na temat wycofania sił koalicyjnych z Iraku. Wówczas jedynie 33\% respondentów opowiedziało się za ewakuacja, natomiast $31 \%$ za kontynuacją operacji i $19 \%$ za wzmocnieniem kadrowym sił koalicji. Podobna tendencja utrzymywała się w następnych miesiącach. Dopiero w sondażu z kwietnia 2004 roku, przeprowadzonym po wydarzeniach madryckich, połowa badanych chciała powrotu PKW (43\% było przeciwnego zdania) i w 48\% akceptowała decyzję władz hiszpańskich dotyczacca wycofania wojsk z Iraku (przy dezaprobacie 38\%) ${ }^{26}$.

Sprzeciw wobec przedłużania polskiego udziału w misji i przekonanie o potrzebie wycofania kontyngentu wzrastały wraz z doniesieniami o ofiarach. W badaniu przeprowadzonym w maju 2004 roku (przy stanie czte-

24 Opinie o udziale Polaków w misji stabilizacyjnej w Iraku, CBOS, komunikat $\mathrm{z}$ badań BS/148/2003 [wersja elektroniczna], http://www.cbos.pl/SPISKOM.POL/2003/K_148_03.PDF [18.05.2008].

25 Polacy o misji stabilizacyjnej w Iraku, CBOS, komunikat z badań BS/180/2003 [wersja elektroniczna], http://www.cbos.pl/SPISKOM.POL/2003/K_180_03.PDF [18.05.2008].

26 Opinie o obecności Polskich żolnierzy w Iraku i zagrożeniu terroryzmem, CBOS, komunikat z badań BS/76/2004 [wersja elektroniczna], http://www.cbos.pl/SPISKOM.POL/2004/K_076_04.PDF [19.05.2008]. 
$\frac{6}{4}$
$\frac{\pi}{8}$
$\frac{\pi}{4}$

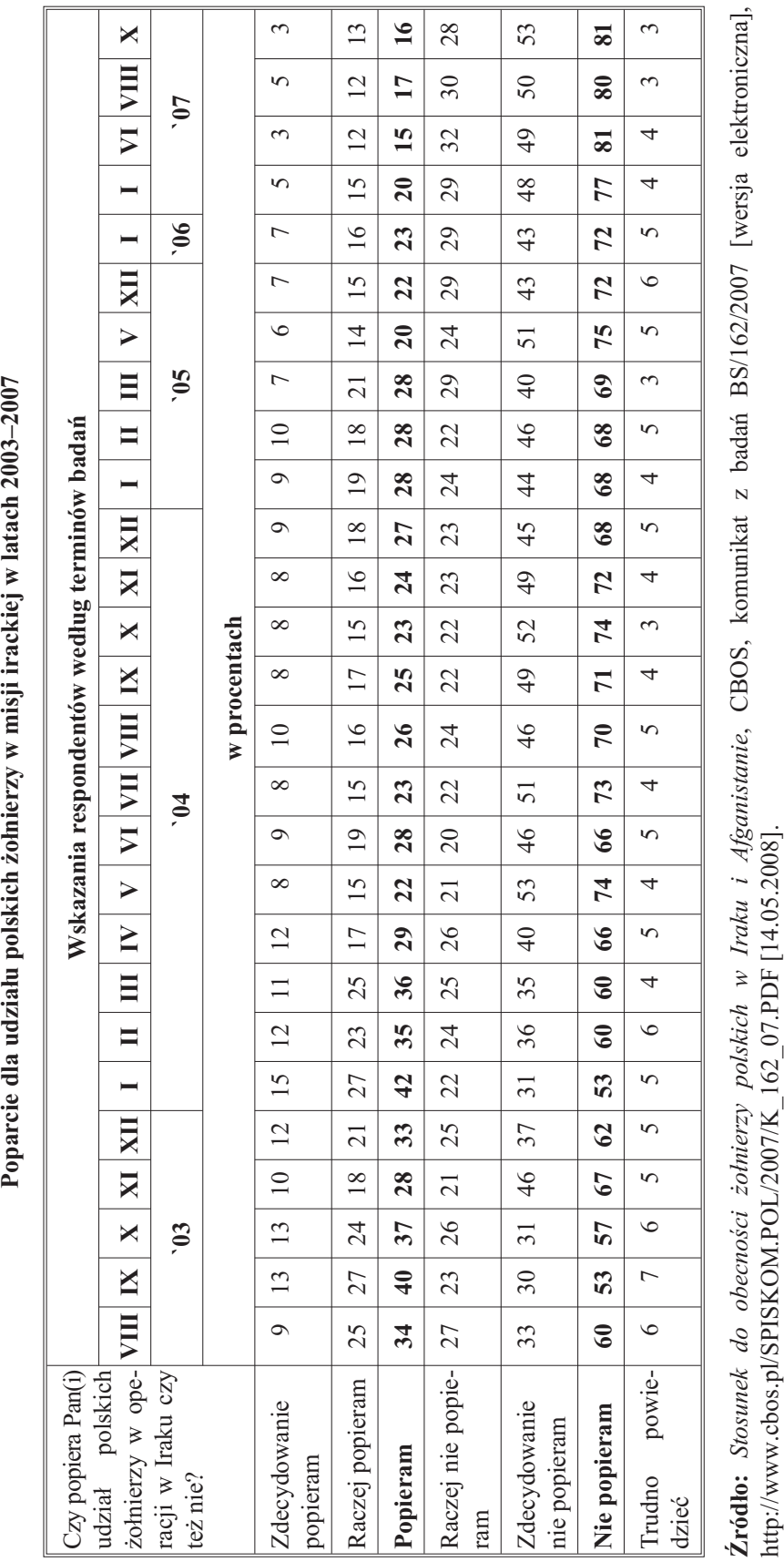


rech zabitych Polaków), aż 74\% respondentów nie aprobowało obecności PKW w Iraku, a 63\% oczekiwało szybkiego powrotu żołnierzy do $\mathrm{kraju}^{27}$. Negatywny stosunek polskiej opinii publicznej do zaangażowania PKW w działania sił koalicyjnych w Iraku był zjawiskiem trwałym i ugruntowanym.

Brak spodziewanych korzyści finansowych i politycznych z udziału w operacji irackiej oraz zamachy na polskich żołnierzy, prowadziły do kontestacji postanowień prezydenta Aleksandra Kwaśniewskiego, a następnie Lecha Kaczyńskiego, o wysyłaniu kolejnych zmian PKW (podjęto łącznie 6 postanowień o przedłużeniu działalności PKW w Iraku). Dezaprobacie wobec obecności PKW w Iraku towarzyszyła niewiara Polaków w sukces misji stabilizacyjnej. Rozwój sytuacji w Iraku nie budził w polskim społeczeństwie nadziei na rychłą poprawę sytuacji, czego dowodem było badanie CBOS z lipca 2004 roku. Większość respondentów (tj. 47\%) uznało, że przekazanie przez Amerykanów władzy tymczasowemu rządowi irackiemu nie wpłynie na normalizację sytuacji w Iraku (29\% prezentowało odmienne zdanie) ${ }^{28}$.

Sondaże prowadzone przez CBOS od czasów zamachów na WTC i Pentagon pokazały, że Polacy nie wierzyli w likwidację terroryzmu w konsekwencji działań koalicji międzynarodowej. Społeczeństwo polskie było przeciwne zaangażowaniu WP w operację iracką i nie wiązało usunięcia dyktatora $\mathrm{z}$ kampanią antyterrorystyczną.

Rozbieżności między stanowiskiem władz a opinią publiczną dotyczyły także celu zaangażowania Polski w misję wojsk koalicyjnych w Iraku. Wśród powodów interwencji, na początku 2003 roku, większość uczestników badań CBOS wskazywała na rozbrojenie Iraku ${ }^{29}$. Mimo zapewnień prezydenta Kwaśniewskiego, że „nie szukaliśmy łatwych zysków ani dostępu do ropy naftowej"30 ${ }^{30}$ od kwietnia 2003 roku ankietowani, podając najważniejszą przyczynę misji irackiej, wybierali przejęcie kon-

27 Spadek poparcia dla polskich żotnierzy w Iraku, CBOS, komunikat z badań BS/86/2004 [wersja elektroniczna], http:/www.cbos.pl/SPISKOM.POL/2004/K 086 04.PDF [19.05.2008].

${ }^{2 \overline{8}}$ Opinie o obecności polskich żolnierzy w Iraku i zagrożeniu terroryzmem, CBOS, komunikat z badań BS/126/04 [wersja elektroniczna], http://www.cbos.pl/SPISKOM.POL/2004/K_126_04.PDF [15.05.2008].

${ }_{29}$ Polacy o misji stabilizacyjnej $w$ Iraku..., op. cit.

30 Cyt. za: Wystąpienie prezydenta A. Kwaśniewskiego na uroczystości pożegnania żołnierzy, udających się do Iraku (Szczecin, 31 lipca 2003 rok), za: J. Bratkiewicz, Zaangażowanie..., op. cit., s. 26-27. 
troli nad złożami ropy naftowej i likwidację dyktatury Saddama Husaj$\mathrm{na}^{31}$. Opinie respondentów wskazywały na fiasko kampanii propagandowej władz, eksponującej walor moralny operacji. Ocenę polityki polskiego rządu komplikowała Koncepcja udziału RP w odbudowie i restrukturyzacji Iraku. Przyjęty 1 lipca 2003 roku, a następnie modyfikowany dokument był dowodem aspiracji polskich władz związanych z misją stabilizacyjną. Zawartym w Koncepcji... oczekiwaniom strony polskiej w kwestii korzyści materialnych, zaprzeczył minister spraw zagranicznych w wystąpieniu sejmowym z 21 stycznia 2004 roku. Zdaniem Włodzimierza Cimoszewicza obecność PKW służyć miała wyłącznie ,przejęciu przez Irakijczyków odpowiedzialności za własną przyszłość" $"$ 22.

Prowadzony przez CBOS na przestrzeni 5 lat monitoring stosunku Polaków do obecności PKW w Iraku pozwala stwierdzić, że dezaprobata wobec misji była zjawiskiem powszechnym u kobiet. W gronie zwolenników dominowali mężczyźni i osoby interesujące się polityką. Ankietowani popierający zaangażowanie Polaków w Iraku wierzyli w powodzenie działań koalicji antyterrorystycznej i byli przeciwni decyzjom o natychmiastowym wycofaniu polskich żołnierzy. Krytycznie oceniali także decyzję premiera José Zapatero o ewakuacji wojsk hiszpańskich z Iraku.

Początkowa wiara w dobre przygotowanie do operacji irackiej, ustapiła miejsca przekonaniu o braku odpowiedniego sprzętu do realizacji powierzonych zadań. Przeświadczenie o niezdolności udźwignięcia ciężaru misji z finansów publicznych było masowe. Większość polskiego społeczeństwa przestała także wierzyć w osiągnięcie przez Polskę korzyści politycznych i finansowych. Przekonanie o dominacji strat nad zyskami, pojawiło się już w ostatnich miesiącach 2003 roku i utrzymało się do końca obecności PKW w Iraku. Jedynie w kwestiach wizerunku Polski na świecie, dostrzegano przewagę korzyści.

Badania nastrojów społecznych wykazały spadek zaufania do polskiej dyplomacji, której efektywność nie budziła wątpliwości na początku kampanii wojennej. Równocześnie ankietowani byli zdania, że zaangażowanie Polski w Iraku wpłynie niekorzystnie na stosunki z Francją i Niemcami,

31 Opinie o obecności polskich żolnierzy w Iraku i o innych interwencjach zbrojnych, CBOS, komunikat z badań BS/75/2005 [wersja elektroniczna], http://www.cbos.pl/SPISKOM.POL/2005/K_075_05.PDF [20.06.2008].

32 Cyt. za.: Informacja rzqdu na temat polskiej polityki zagranicznej 2004 roku..., op. cit., s. 20 . 
natomiast przyniesie profity $\mathrm{w}$ relacjach $\mathrm{z}$ USA i Wielką Brytanią ${ }^{33}$. Z upływem czasu wzrosły także wątpliwości, dotyczące kompetencji PKW w zakresie reagowania na sytuacje kryzysowe. Konsekwencją braku właściwych reakcji na zagrożenia była śmierć 27 Polaków w trakcie pięciu lat trwania misji w Iraku ${ }^{34}$. Jedynie stan i przygotowanie kadry wojskowej były dla większości Polaków wystarczające (zmianę oceny tego aspektu ujawniło badanie $\mathrm{z}$ marca 2005 roku) ${ }^{35}$.

Rozczarowanie interwencją było powszechne, podobnie jak entuzjazm wywołany wnioskiem rządu premiera Donalda Tuska do prezydenta RP o wycofanie polskich żołnierzy $\mathrm{z} \mathrm{Iraku}^{36}$.

$$
* * *
$$

Podsumowując stosunek polskiej opinii publicznej do działań PKW w Afganistanie i Iraku należy zauważyć, że mimo początkowego entuzjazmu z lat 2001-2002, będącego wyrazem solidarności z USA po atakach terrorystycznych na WTC i Pentagon, większość badanych była sceptycznie nastawiona do udziału żołnierzy WP w ,wojnie z terroryzmem”.

\section{Summary}

The attitude of public opinion in Poland towards the activity of the Polish Military Contingent (PMC) in Afghanistan and Iraq was initially (in 2001-2002) quite enthusiastic. This was the consequence of solidarity with the United States after the terrorist attacks on the WTC and the Pentagon. However, even then the majority of respondents were skeptical about the Polish Army's involvement in the 'war on terror'. As time passed by a majority of Polish society no longer believed that Poland would obtain any political or financial benefits. The conviction that the losses had prevailed over the benefits emerged at the end of 2003 and it remained until the PMC deployment in Iraq ended. The benefits were only perceived in terms of the global image of Poland.

33 Skutki zaangażowania Polski w Iraku, CBOS, komunikat z badań BS/18/2005 [wersja elektroniczna], http://www.cbos.pl/SPISKOM.POL/2005/K_018_05.PDF [21.06.2008].

34 W tym 22 żołnierzy, 2 dziennikarzy, 2 byłych komandosów GROM pracujących dla firmy zagranicznej i 1 funkcjonariusza Biura Ochrony Rządu, który zginął 3 października 2007 roku w zamachu na ambasadora RP w Iraku gen. Edwarda Pietrzyka.

${ }^{35}$ Opinie o obecności polskich żotnierzy w Iraku i o innych..., op. cit.

36 Por. wyniki badań przeprowadzonych przed wnioskiem rządu do prezydenta O terminie wycofania żotnierzy polskich z Iraku, stosunku do ulokowania w Polsce elementów tarczy antyrakietowej, CBOS, komunikat z badań BS/176/2007 [wersja elektroniczna], http://www.cbos.pl/SPISKOM.POL/2007/K_176_07.PDF [22.06.2008]. 